How Access to Urban Potable Water and Sewerage Connections Affects Child Mortality

Anqing Shi
Lower child mortality is associated with improved access to urban potable water and sewerage connections. government involvement in the provision of local water services, and private or parastatal participation in the provision of sewerage connections.

The World Bank

Development Research Group

Finance

January 2000 
Policy Research Working Paper 2274

\section{Summary findings}

Using a city-level database of Global Urban Indicators, Shi finds that:

- Improved access to urban potable water and sewerage connections is consistently associated with low child mortality.

- Government involvement in providing water services, especially locally, significantly reduces child mortality.

- Private or parastatal participation in providing sewerage connections is associated with low child mortality.

- Rapid urban growth and high levels of poverty within the city are correlated with high child mortality.

This paper - a product of Finance, Development Research Group - is part of a larger effort in the group to study the relationship between finance and poverty reduction. Copies of the paper are available free from the World Bank, $1818 \mathrm{H}$ Street, NW, Washington, DC 20433. Please contact Paulina Sintim-Aboagye, room MC3-422, telephone 202-473-7644, fax 202-522-1155, email address psintimaboagye@worldbank.org. Policy Research Working Papers are also posted on the Web at www.worldbank.org/research/workingpapers. The author may be contacted at ashi@worldbank.org. January 2000. (31 pages)

The Policy Research Working Paper Series disseminates the findings of work in progress to encourage the exchange of ideas about development issues. An objective of the series is to get the findings out quickly, even if the presentations are less than fully polished. The papers carry the names of the authors and should be cited accordingly. The findings, interpretations, and conclusions expressed in this paper are entirely those of the authors. They do not necessatily represent the view of the World Bank, its Executive Directors, or the conntries they represent. 


\title{
How Access to Urban Potable Water and Sewerage Connections Affects Child Mortality
}

\author{
Anqing Shi \\ Finance \\ Development Research Group \\ World Bank \\ Email address: ashi@worldbank
}

I gratefully thank Gerard Caprio, George Clarke, Bob Cull, Lionel Demery, Halsey Rogers, and Lyn Squire for very helpful comments. 



\section{Introduction}

Child mortality (children under age 5) varies greatly around the world, ranging from 0.8 per 1,000 live births in Rennes, France, to 320 per 1,000 live births in Luanda, Angola in 1993 (Flood 1997). Although the effects of nutrition, education, and health programs on child mortality in rural areas are well documented, the roles of access to potable water and sewerage connection in reducing child mortality in urban areas have not been well researched.

Over the last two decades, vigorous efforts have been made to improve access to potable water and sewerage connection in urban areas. The United Nations General Assembly proclaimed 19811990 as the International Drinking Water Supply and Sanitation Decade. Many member countries assumed a commitment to improve the quality of and access to potable water and the sewerage system by the year 1990 . However, at the end of the 1980 s, the situation had not improved greatly. Global Urban Indicators data show that in many cities around the world one quarter of households did not have access to the potable water within 200 meters from their living places in 1993 (Auclair 1998); most poor people do not have an adequate disposal system (Briscoe 1992). The problem will become more serious in the years to come as city population continue to grow rapidly. It is projected that by year 2030 , the urban population will grow to 3.3 billion, over 90 percent of which will accrue to cities of developing countries (UNCHS 1997).

In this context, this paper examines how access to potable water and sewerage connection affects child mortality in cities worldwide, using 1993 city level data available from Global Urban Indicators, a product of the United Nations Center for Human Settlements (UNCHS). The results clearly show that improved access to potable water and sewerage connection are associated with lower child mortality. In addition, greater government involvement in the water service management, especially at the local level, significantly reduces child mortality; private or parastatal participation in 
sewerage provision is associated with a lower child mortality. Controlling for the city revenue from central government transfers, a higher percentage of city revenue derived from local taxes is associated with lower child mortality. Rapid urban population growth and higher poverty level within a city lead to higher child mortality.

The paper is organized as follows: in the next section, we briefly review the literature on the roles of access to potable water and sewerage connection on child mortality, and the impact of urban growth and urban management on child mortality. This is followed by a description of the data, variable construction, and empirical findings. The final section will highlight major conclusions and implications for policy formation.

\section{Literature}

The literature on the determinants of child mortality has suggested a strong inverse correlation between access to urban water as well as sewerage connection on the one hand and child mortality on the other (Feachem 1981; Schultz 1980; World Health Organization 1978). Increase in the amount of water used and wide coverage of sewerage connection contribute to better hygiene and to the elimination of bacteriological contamination. Puffer and Serrano (1973) studied infant and child mortality in several Latin American cities and found that a high proportion of households reporting infant deaths lacked adequate water sources. In a study on the mortality variation in urban Brazil, Merrick (1985) found that access to piped water in a household is likely to be of most direct benefit in lowering child mortality by reducing exposure to water-borne diseases, particularly diarrhea. In a study of regional variation of infant and child mortality in Sri Lanka, Patel (1981) found that the

supply of well-water and presence of latrines explained substantial regional variation in mortality. 
Although there is continuing interest in studying the roles of urban water supply and sewerage connection on child mortality, recent research on child mortality differentials has focused on the impact of city growth. The findings have suggested that, on average, large city residents enjoyed favorable living conditions as compared with other urbanites, as a result of concentration of publicly financed services, infrastructure, and the highest incomes in the large cities (Harrison 1982). However, since the later 1980 s, this conventionally presumed superiority of large cities has been widely questioned, as rapid urban population growth was unchecked, resulting in a deteriorating environment and insufficient infrastructure, which, in turn, worsened the level of child survival. The rapid city growth has also gone hand in hand with growing inequality within cities, pushing the poor to a worsening position in their living condition. Child mortality rates were several times higher in slums and periurban areas than in more privileged neighborhoods (Harpham et al 1988; Stephens 1996; Timaeus and Lush 1995).

Another strand of recent research on child mortality concerns the impact of the political economy of cities, with particular focus on possible impacts of urban revenue resources and urban management on child mortality (Cheema 1992, Minujin 1995; Stren 1995). The economic restructuring in many countries and the world financial crises since the 1980 s have impacted on the well being of residents in major cities, mainly through declining public expenditure on municipal services, housing, and infrastructure (Demery and Squire 1996; Gilbert 1993). Brockerhoff and Brennan (1998) used the level of infant mortality to compare well being across cities of one million or more residents and smaller settlements within developing regions. They found that the pronounced early infant survival advantage of big city residents in Latin America and the Caribbean declined steadily since the late 1970s and was no longer apparent by the early 1990s. The reason was that these big-cities, where finance and trade were concentrated, have been exposed to volatile capital outflows. Sharp reductions 
in expenditure led to a worsening of nutritional levels and to an exclusion from access to public utilities such as water access and sanitation. As a result, the earlier infant survival advantage was substantially reduced.

Infant and child survival rates were affected not only through reduced public expenditure on city infrastructure, but also through the way in which the urban infrastructure was managed. One important aspect of urban infrastructure management is water and sewerage system provision and delivery. Recent urban studies suggest that it is necessary to have empowered coordinating bodies at the local level, which incorporate indigenous urban institutions into a program, to implement service provision effectively (McCarney, Halfani, and Rodriguez 1995; Werna 1996). In addition, active involvement by the private sector in bridging supply-demand discrepancies in city service is also considered a necessary step to ensure the welfare of the city population (Briscoe 1992).

By taking these prevailing views into consideration, this paper proposes two hypotheses regarding to the urban living conditions: (1) the higher the percentage of population able to access potable water or sewerage connection, the lower the child mortality; (2) equally important, the greater the local government involvement and private sector participation in managing and delivering water and sewerage service, the lower the child mortality.

\section{Data, variables, and empirical model}

The Global Urban Indicators were collected for 237 cities in 110 countries by the United Nations Center for Human Settlements (UNCHS) in 1993, providing a global picture of urban conditions. About three quarters are in developing countries. There are 46 key indictors in 8 modules: demographic data, socioeconomic development, infrastructure, transportation, environmental management, local government, housing affordability and adequacy, and housing provision. A good 
range of city sizes is represented in the data: 34 percent are cities of less than 0.3 million people, $29 \%$ are cities with 0.3-1.0 million people, and $37 \%$ are cities with more than 1 million (Auclair 1998).

City information was gathered by data collectors assigned by Global Urban Observatory of UNCHS who were asked to make best use of secondary sources for indicators wherever possible, or otherwise to make use of an expert focus group, conducting an impromptu survey, or using other estimation techniques (Auclair 1998). Many of the data provided were of surprisingly good quality, particularly from the poorer countries which are often considered to have low capacity for data collection (Flood 1997). Due to missing values on some variables in various model specifications, the usable samples of this study range from 92 to 58 observations, depending on the model specification. The definition of all variables is presented in Table 1.

We model the level of child mortality as a function of access to potable water or sewerage connection, city growth, local revenue resources, and water or sewerage services management. The relationship between potable water access or sewerage connection and child mortality is first examined in specification 1, with two control variables included: population per hospital bed, a proxy for the general level of adequacy of health services, and household income per capita. These two control variables are commonly used as the predictors in both individual or aggregate level analysis of child mortality.

The relationship between water access or sewerage connection and child mortality is further examined by controlling for a demographic variable, city population growth, which has been found to be positively correlated with child mortality. The model further controls for income distribution within the city, proxied by the percentage of households below the poverty line. The reason to include an income distribution variable in the model is that, as recent literature suggests, not only is the decline in child mortality associated with the level of economic development, but also is associated with the 
income inequality within the city as discussed in the previous section. A recent country study by World Bank (1998) shows that in India the distribution of water access and sanitation varies across income categories; the wealthier have far better access to piped and other exclusive sources of water than the poor.

We finally introduce a water access or a sewerage service provider variable and two city revenue resource variables. Fortunately, Global Urban Indicators includes information regarding the water and sewerage service provisions and we use them to see if service provision is responsible for some of the variation in child mortality. In some countries, local government (i.e., at city level) has very few responsibilities, and instead parastatal and private providers are heavily involved; while in others it is the local government that is virtually responsible for whole range of local services, including the management of potable water access and sewerage connection. The type of provider is captured by a series of dummy variables: parastatal and private sectors (the reference group), local government alone, national or regional government alone, both local and national governments, and a mixture of public and nonpublic sectors.

City revenue resources are captured by two variables taken from the Global Indicator Data: the percentage of city revenue from local taxes and the percentage of city revenue from transfers from the central government. It is expected that, given the level of transfers from the central government, adequate city revenue (i.e., higher local revenue from taxes) will lead to better city welfare (i.e., lower child mortality). The coefficients are estimated using OLS regression, and White's (1980) procedure for calculating standard errors is used to correct for heteroscedasticity.

The basic specification takes following form

$$
M=a+b P+c S_{i}+d X+u
$$


Where $M$ is the child mortality rate, $P$ is either the percentage of city residents with access to potable water in city or the percentage of households with sewerage connection in the city, $\mathrm{S}_{\mathrm{i}}$ is a series dummies capturing the type of organizations responsible for water or sewerage provision (e.g, local government alone, central government alone, both local and central governments, private or parastatal sector, and mixture of type of providers), $\mathbf{X}$ is a set of control variables, and $\mathrm{u}$ is the residuals.

\section{Findings}

The descriptive statistics for all variables used in this study is presented in Table 2-1 for the water access equation and Table 2-2 for the sewerage connection equation. The child mortality rate is 55.5 per 1,000 live births on average for the cities in the sample. There is a large variation in child mortality rates across cities, with coefficients of variation (S.D/mean) reaching 0.95 . The average level of potable water access in this sample is 86.9 percent, with one standard deviation of 17.5 percent. $53 \%$ of households have a sewerage connection, which is lower than the figure for access to potable water. However, the sewerage connection variable exhibits greater variation than the potable water access variable, with one standard deviation of 37.98 percent.

The child morality rate is inversely correlated with access to potable water $(r=-0.68)$ and sewerage connection $(r=-0.66)$. City growth is positively correlated with the level of child mortality $(\mathrm{r}=0.59)$, as is the percentage of households below the poverty line in the city $(\mathrm{r}=0.36)$. In addition, the lack of health services facilities (measured by a higher number of persons per hospital bed) is also associated with higher child mortality $(r=0.40)$. Finally cities with higher household income per capita have lower child mortality $(r=-0.39)$.

Tables 2-1 and 2-2 also suggest that the types of water and sewerage service providers are associated with level of child mortality. A local government as water or sewerage service provider, for 
example, is consistently associated with a lower child mortality. By contrast, a parastatal or private provider for water service is likely associated with a higher mortality; but it is not true in case of sewerage connection service provision in which the private or parastatal provider group is associated with low child mortality. The city's financial resources, local revenue from taxes and local revenue from central government transfers, are not significantly associated with the child mortality rate.

Tables 2-1 and 2-2 further show that potable water access and sewerage connection varies with household income per capita, city growth, and government involvement in services provision. Higher income per capita is clearly associated with higher water access and sewerage connection. The poverty level within cities is inversely associated with water access, but not sewerage connection. Furthermore, rapid city growth is associated with lower access to potable water and sewerage connection. Finally, a local government provider is significantly associated with both higher coverage of city potable water $(r=0.18)$ and household sewerage connection $(r=0.27)$.

This bivariate relationship between potable water access and sewerage connection on the one hand and child mortality on the other is further examined in regression models in Table 3-1 and Table 3-2 respectively. Specification 1 of Table 3-1 only includes the water access variable and two control variables: household income per capita and population per hospital bed. The results confirm an inverse relationship between access to potable water and child mortality. Also, as expected, that higher household income per capita is associated with lower child mortality, while the inadequacy of health services is correlated with higher child mortality.

This inverse relationship between water access and child mortality is further examined in specification 2 where city growth is introduced. Findings suggest that the inverse relationship between 
potable water access and child mortality remains even when city growth variable is controlled for. ${ }^{1}$ However, the magnitude of this inverse association is reduced, suggesting that the impact of access to potable water on child mortality is partially cancelled out by city growth. In other words, rapid city growth could reduce the impact of water access on child mortality. In addition, city growth itself is associated with higher child mortality.

We further examine the inverse relationship between the access to potable water and child mortality by introducing another variable, the percentage of households under the poverty line (specification 3). ${ }^{2}$ The result suggests that the inverse association between potable water access and child mortality remains; but the magnitude of this inverse association declines, suggesting that the role of access to potable water on child mortality could be offset partially by a high poverty level.

In specification 4 , two sets of variables, types of water service provider and city revenue resources, are brought into the model. The results further confirm a significant inverse relationship between access to potable water and child mortality. Specifically, the estimated coefficient implies that a one standard-deviation increase $(17.5 \%)$ in potable water access would decrease child mortality by nearly 15 per 1,000 . In addition, city revenue resources do have independent effects on child mortality. Controlling for the level of revenues obtained from central government, a higher percentage of city revenue from local taxes is associated with lower child mortality. Furthermore, water access managed by local or by national government is clearly associated with lower child mortality compared to that managed by parastatal or private sector.

\footnotetext{
${ }^{1}$ When we introduce the population size of city as an additional variable in the model by coding them as series of dummy variables, the result remains the same. However, the sample size reduces greatly due to the missing values for the city size variable. Thus, we do not present this specification in the paper.

${ }^{2} \mathrm{~A}$ better measurement of income inequality in a city is the household income disparity (Q5/Q1), a ratio of the income of highest quintile over lowest quintile. We have tried to use this variable; however, the coefficient turns out to be
} 
Table 3-2 shows the findings on the impact of sewerage connection on child mortality. Specification 1 only includes the sewerage connection variable and two other control variables, household income per capita and population per hospital bed. The inverse relationship between the level of household sewerage connection and child mortality is confirmed. In specifications 2 and 3, we further examine the relationship between sewerage connection and child mortality by introducing a city growth variable and a city poverty level variable sequentially. The result shows that the inverse relationship between sewerage connection and child mortality remains, although the magnitude of the relationship is reduced somewhat when these two variables are controlled for. In addition, as expected, rapid city growth and higher poverty levels are associated with higher child mortality.

In model 4, we incorporate another two sets of variables, type of providers in sewerage connection and city revenue resources, into the model. Results of this specification further support the inverse association between the level of sewerage connection and child mortality. The estimated coefficient implies that a one-standard-deviation increase in household sewerage connection would decline child mortality rate by nearly 18 per 1,000 . In addition, private or parastatal sector's provision of sewerage connection, which is the reference group, is associated with lower child mortality compared with that of the public sector. This result is quite in contrast to the potable water access equation of Table 3-1 in which private sector participation in water service provision is associated with higher child mortality.

To examine the impact of water access and sewerage connection on child mortality more clearly, the predicted rates of child mortality are calculated from specification 4 of Table 3-1 and Table 3-2 at different levels of water access and sewerage connection by holding all other variables constant

insignificant. The simple correlation also suggests this variable does not significantly correlate with child mortality. Hence we drop this variable. 
at their means. The results are shown in Table 4. The results suggest that if coverage of potable water access increases from the current mean level of 86 percent to 95 percent, the child mortality rate would decline from 46 per 1,000 to 39 per 1,000 . If the level of potable water access is set at 70 percent, which is the figure for most cities in Africa, the child mortality would reach as high as 60 per 1,000. Similarly, an increase in household sewerage connection is also associated with a decline of child mortality. For example, if the household sewerage connection increases from its current mean level of 53 percent to 60 percent, the child mortality rate would decline from 77 per 1,000 to 74 per 1,000 . If the level of sewerage connection were as low as 15 percent, which is the average level for most African countries, the child mortality would reach 95 per 1,000.

\section{Robustness}

To check the robustness of these results, we consider robustness along three dimensions. First, the level of access to potable water and household sewerage connection might be endogenous in their child mortality equations, and treating them as exogenous variables could incur simultaneity bias in the estimations. To check whether such biases have driven our estimations, we run two-stage least square regressions (2SLS) in which the access to potable water and household sewerage connection are treated as endogenous variables. The instruments include a constant, household income per capita, the percentage of population under poverty line, urban growth, and local government variables such as the percentage of local revenue from central government transfers, the percentage of local revenue from local tax, local government autonomy in setting service use fees, and type of service providers . Column (1) of Table 5-1 reports the IV estimation for the potable water access equation. The results clearly confirm the findings in OLS regressions: a higher percentage of access to potable water is associated with a lower child mortality $(t=3.4)$, and furthermore, the magnitude of this inverse 
association is even larger than that implied by the OLS regression. Column (2) of Table 5-2 reports the IV estimation of the sewerage connection equation. The results also confirm the inverse association between sewerage connection and child mortality revealed in the OLS regression: a higher percentage of household sewerage connection is associated with lower child mortality $(t=3.68)$. Moving from OLS to IV also does not change the estimated impacts of other variables in the model. Thus the OLS results are robust.

Second, we are concerned about a potential sample section problem. Due to the missing values on variables we used in this study, the sample is relatively small, ranging from 92 to 58 , depending on the specification. Thus, efforts have been made to increase the sample size to see if the relationship between access to potable water and sewerage connection on one hand and child mortality on the other still holds. We have taken comparable statistics on city growth, urban water access, urban sanitation access, and income per capita (in constant US dollar) from the World Bank data source (SIMA) to substitute for the missing values. As a result, 48 cities are added. ${ }^{3}$

Regression results for the extended sample are presented in Table 5-2 and 5-3. The findings from Table 5-2 indicate that the inverse association between water access and child mortality remains firm, and the magnitude in fact becomes even larger. The coefficient is -0.83 in the original sample (specification 4), and it is -1.41 in the extended sample (specification 4). The results for other variables in the Table remain more or less the same. The inverse relationship between sewerage connection and child mortality is also confirmed for the extended sample in Table 5-3, and the magnitudes become even stronger than those in the original sample.

\footnotetext{
${ }^{3}$ Please see the list of added cities in the appendix 2.
} 
The third concern is the possibility that the results were driven by the systematic differences among different regions of the world (Frankel and Romer 1999). To address this concern, we reestimate the regressions in Table 3-1 and Table 3-2 including a series of dummies for four regions. Results are presented in Table 5-4. These specifications also confirm the results revealed in Table 3-1 and 3-2: there is an inverse association between potable water access and child mortality (coefficient $=$ -1.03 ) and an inverse association between sewerage connection and child mortality (coefficient $=$ 0.59). Thus, sensitivity analyses through two-stage least squares, expanding the sample size, and inclusion of regional dummies demonstrate the robustness of the original results.

\section{Conclusion}

The 1990 World Development Report (World Bank 1990) claimed that urban poverty would become the most significant, and politically explosive, problem of the next century. Therefore, there is an urgent need to study the current living conditions in urban areas. In this context, this paper examines one of the dimensions of well being in cities, child mortality, which can be compared across highly diverse urban populations worldwide.

The findings of this paper do not suggest a narrowly demographic determinant of well being in cities (i.e., population growth pressures); nor do they suggest that economic development alone, as measured by household income per capita, could lead to a lower child mortality regime. Rather, other political and financial aspects of cities are equally important. As evidenced in this paper, higher child mortality is also attributed to the problems found in urban areas worldwide---inadequate potable water access and sewerage connections; income inequality within a city, lack of government commitment, especially at the city level, over water services management, lack of private sector participation in sewerage system provision, and lack of sufficient revenue at the city level. These findings confirm a 
view shared by the 1996 UN Global Conference on Human Settlements, HABITATT II, and recent urban theorists who point to the adequacy of water access as well as sewerage connections and the efficiency of urban management as the critical components affecting the child mortality in urban areas (Mills and Becker 1986; Prudh' homme 1994). 
Table 1 Variables used in the study: 1993

Variable Definition

\section{Child mortality}

Access to portable water

Household's sewerage connections

Household income per capita

Population per hospital bed

Household below poverty line

Type of water or sewerage service providers

City revenue from Central government City revenue from local tax

Urban growth
Number of children dead before reaching the age of five per 1,000 live births.

Percentage of households accessible to the potable within 200 meters from their housing.

Percentage of households connected to the sewerage system.

Household income per capita in 1993 \$US in (100s).

Population per hospital bed (in 10s).

Percentage of households below the locally defined Poverty line.

Providers are dummy variables:

Local government alone;

National and regional governments alone;

Combination of local, regional, and national governments;

Parastatal and private sectors (reference group);

Mixture of type of providers.

Percentage of local revenue coming from central government transfers. Percentage of local revenue coming from local tax.

Population growth rate (per 1,000). 
Table 2-1. The Means and Standard Deviations and Correlation of variables used in the study, 1993

\begin{tabular}{|c|c|c|c|c|c|c|c|c|c|c|c|c|c|}
\hline & $\begin{array}{l}\text { Child } \\
\text { Morality }\end{array}$ & (1) & (2) & (3) & (4) & (5) & (6) & (7) & (8) & (9) & $(10)$ & (11) & (12) \\
\hline (1) & $\begin{array}{c}-0.3851 \\
(0.0002)\end{array}$ & & & & & & & & & & & & \\
\hline (2) & $\begin{array}{c}0.4015 \\
(0.0001)\end{array}$ & $\begin{array}{l}-0.2006 \\
(0.055)\end{array}$ & & & & & & & & & & & \\
\hline (3) & $\begin{array}{l}-0.6814 \\
(0.0001)\end{array}$ & $\begin{array}{l}0.3256 \\
(0.0001)\end{array}$ & $\begin{array}{l}-0.3201 \\
(0.0001)\end{array}$ & & & & & & & & & & \\
\hline (4) & $\begin{array}{l}0.3627 \\
(0.0009)\end{array}$ & $\begin{array}{l}-0.2253 \\
(0.0431)\end{array}$ & $\begin{array}{l}0.2579 \\
(0.0201)\end{array}$ & $\begin{array}{c}-0.2294 \\
(0.0394)\end{array}$ & & & & & & & & & \\
\hline (5) & $\begin{array}{l}0.0655 \\
(0.5614)\end{array}$ & $\begin{array}{l}-0.1210 \\
(0.2820)\end{array}$ & $\begin{array}{c}-0.1032 \\
(0.3593)\end{array}$ & $\begin{array}{l}-0.1240 \\
(0.2699)\end{array}$ & $\begin{array}{l}-0.0503 \\
(0.6725)\end{array}$ & & & & & & & & \\
\hline (6) & $\begin{array}{l}-0.0626 \\
(0.5813)\end{array}$ & $\begin{array}{l}0.0910 \\
(0.4221)\end{array}$ & $\begin{array}{l}0.1828 \\
(0.1047)\end{array}$ & $\begin{array}{l}0.0970 \\
(0.3921)\end{array}$ & $\begin{array}{l}02501 \\
(0.0328)\end{array}$ & $\begin{array}{l}-0.6859 \\
(0.0001)\end{array}$ & & & & & & & \\
\hline (7) & $\begin{array}{l}0.5901 \\
(0.0001)\end{array}$ & $\begin{array}{l}-0.3451 \\
(0.0008)\end{array}$ & $\begin{array}{l}0.3713 \\
(0.0003)\end{array}$ & $\begin{array}{l}-0.4887 \\
(0.0001)\end{array}$ & $\begin{array}{l}0.0736 \\
(0.5138)\end{array}$ & $\begin{array}{l}0.0073 \\
(0.9481)\end{array}$ & $\begin{array}{l}-0.0715 \\
(0.5283)\end{array}$ & & & & & & \\
\hline (8) & $\begin{array}{l}-0.2218 \\
(0.0336)\end{array}$ & $\begin{array}{l}0.1836 \\
(0.0799)\end{array}$ & $\begin{array}{l}0.0428 \\
(0.6856)\end{array}$ & $\begin{array}{l}0.1750 \\
(0.0953)\end{array}$ & $\begin{array}{l}-0.0481 \\
(0.6696)\end{array}$ & $\begin{array}{l}-0.0470 \\
(0.6768)\end{array}$ & $\begin{array}{c}-0.0346 \\
(0.7604)\end{array}$ & $\begin{array}{c}-0.1125 \\
(0.2859)\end{array}$ & & & & & \\
\hline (9) & $\begin{array}{l}-0.0561 \\
(0.5953)\end{array}$ & $\begin{array}{l}-0.1780 \\
(0.0896)\end{array}$ & $\begin{array}{l}-0.0618 \\
(0.5583)\end{array}$ & $\begin{array}{c}-0.0407 \\
(0.7003)\end{array}$ & $\begin{array}{c}-0.2273 \\
(0.0413)\end{array}$ & $\begin{array}{l}0.1079 \\
(0.3378)\end{array}$ & $\begin{array}{c}-0.1490 \\
(0.1873)\end{array}$ & $\begin{array}{l}0.0925 \\
(0.3804)\end{array}$ & $\begin{array}{c}-0.3834 \\
(0.0002)\end{array}$ & & & & \\
\hline (10) & $\begin{array}{l}-0.0123 \\
(0.9071)\end{array}$ & $\begin{array}{l}-0.1140 \\
(0.2794)\end{array}$ & $\begin{array}{l}-0.0257 \\
(0.8079)\end{array}$ & $\begin{array}{l}0.0577 \\
(0.5847)\end{array}$ & $\begin{array}{l}0.1500 \\
(0.1814)\end{array}$ & $\begin{array}{l}-0.2048 \\
(0.0666)\end{array}$ & $\begin{array}{l}0.3157 \\
(0.0043)\end{array}$ & $\begin{array}{l}0.0143 \\
(0.8923)\end{array}$ & $\begin{array}{c}-0.2133 \\
(0.0412)\end{array}$ & $\begin{array}{c}-0.2192 \\
(0.0358)\end{array}$ & & & \\
\hline (11) & $\begin{array}{l}0.2581 \\
(0.0130)\end{array}$ & $\begin{array}{l}-0.0027 \\
(0.9797)\end{array}$ & $\begin{array}{l}0.0445 \\
(0.6737)\end{array}$ & $\begin{array}{c}-0.0201 \\
(0.8498)\end{array}$ & $\begin{array}{l}0 .{ }^{\prime} 52 \\
(0.3058)\end{array}$ & $\begin{array}{l}0.2241 \\
(0.0443)\end{array}$ & $\begin{array}{c}-0.0959 \\
(0.3977)\end{array}$ & $\begin{array}{l}0.1090 \\
(0.3009)\end{array}$ & $\begin{array}{l}-0.1753 \\
(0.0947)\end{array}$ & $\begin{array}{c}-0.1801 \\
(0.0858)\end{array}$ & $\begin{array}{c}-0.1002 \\
(0.3419)\end{array}$ & & \\
\hline (12) & $\begin{array}{l}0.0689 \\
(0.5142)\end{array}$ & $\begin{array}{l}-0.1384 \\
(0.1883)\end{array}$ & $\begin{array}{l}0.0573 \\
(0.5876)\end{array}$ & $\begin{array}{c}-0.0769 \\
(0.4665)\end{array}$ & $\begin{array}{l}0.2408 \\
(0.0303)\end{array}$ & $\begin{array}{l}-0.1296 \\
(0.2489)\end{array}$ & $\begin{array}{l}0.2227 \\
(0.0471)\end{array}$ & $\begin{array}{l}0.0312 \\
(0.7682)\end{array}$ & $\begin{array}{c}-0.2366 \\
(0.0232)\end{array}$ & $\begin{array}{l}-0.2431 \\
(0.0196)\end{array}$ & $\begin{array}{l}-0.1353 \\
(0.1986)\end{array}$ & $\begin{array}{l}-0.1111 \\
(0.2915)\end{array}$ & \\
\hline $\begin{array}{l}\text { Mean* } \\
\text { Std Dev } \\
\text { Obs }\end{array}$ & $\begin{array}{l}55.5163 \\
52.5405 \\
92\end{array}$ & $\begin{array}{l}17.80 \\
35.20 \\
92\end{array}$ & $\begin{array}{l}42.10 \\
61.81 \\
92\end{array}$ & $\begin{array}{l}86.8920 \\
17.5665 \\
92\end{array}$ & $\begin{array}{l}27.8004 \\
22.8479 \\
81\end{array}$ & $\begin{array}{l}44.8231 \\
24.1077 \\
81\end{array}$ & $\begin{array}{l}20.2589 \\
25.1500 \\
80\end{array}$ & $\begin{array}{l}26.8391 \\
22.8479 \\
92\end{array}$ & $\begin{array}{l}0.3125 \\
0.4664 \\
80\end{array}$ & $\begin{array}{l}0.3250 \\
0.4713 \\
80\end{array}$ & $\begin{array}{l}0.1250 \\
0.3328 \\
80\end{array}$ & $\begin{array}{l}0.0875 \\
0.2843 \\
80\end{array}$ & $\begin{array}{l}0.1500 \\
0.3593 \\
80\end{array}$ \\
\hline \multicolumn{14}{|c|}{$\begin{array}{l}\text { P values in parentheses. } \\
\text { (1) Household income per capita } \\
\text { (2) Population per hospital bed } \\
\text { (3) Access to potable water } \\
\text { (4) Household below poverty line } \\
\text { (5) Revenue from government } \\
\text { (6)Revenue from local tax } \\
\text { (7) City growth } \\
\text { (8) local government alone as water service provider } \\
\text { (9) Central government alone as water service provider } \\
\text { (10) Both local and central governments } \\
\text { (11) Parastatal and private sectors as water service provider } \\
\text { (12) mix of all type of providers } \\
\text { * means for dummy variables of water access providers are }\end{array}$} \\
\hline
\end{tabular}


Table 2-2. The Means and Standard Deviations and Correlation of variables used in the study, 1993

\begin{tabular}{|c|c|c|c|c|c|c|c|c|c|c|c|c|c|}
\hline : & $\begin{array}{l}\text { Child } \\
\text { Morality }\end{array}$ & (1) & (2) & (3) & (4) & (5) & (6) & (7) & (8) & (9) & (10) & (11) & (12) \\
\hline (1) & $\begin{array}{l}-0.3851 \\
(0.0002)\end{array}$ & & & & & & & & & & & & \\
\hline (2) & $\begin{array}{c}0.4015 \\
(0.0001)\end{array}$ & $\begin{array}{l}-0.2006 \\
(0.055)\end{array}$ & & & & & & & & & & & \\
\hline (3) & $\begin{array}{l}-0.6560 \\
(0.0001)\end{array}$ & $\begin{array}{l}0.4606 \\
(0.0001)\end{array}$ & $\begin{array}{l}-0.2981 \\
(0.0041)\end{array}$ & & & . & & & & & & & \\
\hline (4) & $\begin{array}{l}0.3627 \\
(0.0009)\end{array}$ & $\begin{array}{l}-0.2253 \\
(0.0431)\end{array}$ & $\begin{array}{l}0.2579 \\
(0.0201)\end{array}$ & $\begin{array}{l}-0.1040 \\
(0.3584)\end{array}$ & & & & & & & & & \\
\hline (5) & $\begin{array}{l}0.0655 \\
(0.5614)\end{array}$ & $\begin{array}{l}-0.1210 \\
(0.2820)\end{array}$ & $\begin{array}{l}-0.1032 \\
(0.3593)\end{array}$ & $\begin{array}{c}-0.0483 \\
(0.6727)\end{array}$ & $\begin{array}{l}-0.0503 \\
(0.6725)\end{array}$ & & & & & & & & \\
\hline (6) & $\begin{array}{l}-0.0626 \\
(0.5813)\end{array}$ & $\begin{array}{l}0.0910 \\
(0.4221)\end{array}$ & $\begin{array}{l}0.1828 \\
(0.1047)\end{array}$ & $\begin{array}{l}0.0349 \\
(0.7615)\end{array}$ & $\begin{array}{l}0.0251 \\
(0.0328)\end{array}$ & $\begin{array}{l}-0.6859 \\
(0.0001)\end{array}$ & & & & & & & \\
\hline (7) & $\begin{array}{l}0.5901 \\
(0.0001)\end{array}$ & $\begin{array}{l}-0.3451 \\
(0.0008)\end{array}$ & $\begin{array}{l}0.3713 \\
(0.0003)\end{array}$ & $\begin{array}{l}-0.5220 \\
(0.0001)\end{array}$ & $\begin{array}{l}0.0736 \\
(0.5138)\end{array}$ & $\begin{array}{l}0.0073 \\
(0.9481)\end{array}$ & $\begin{array}{c}-0.0715 \\
(0.5283)\end{array}$ & & & & & & \\
\hline (8) & $\begin{array}{l}-0.2576 \\
(0.0137)\end{array}$ & $\begin{array}{l}0.1403 \\
(0.1848)\end{array}$ & $\begin{array}{l}-0.0029 \\
(0.9786)\end{array}$ & $\begin{array}{l}0.2726 \\
(0.0089)\end{array}$ & $\begin{array}{l}0.0228 \\
(0.8407)\end{array}$ & $\begin{array}{l}-0.0126 \\
(0.9124)\end{array}$ & $\begin{array}{c}-0.0011 \\
(0.9924)\end{array}$ & $\begin{array}{l}-0.1065 \\
(0.3151)\end{array}$ & & & & & \\
\hline (9) & $\begin{array}{l}0.0540 \\
(0.6113)\end{array}$ & $\begin{array}{l}-0.1184 \\
(0.2638)\end{array}$ & $\begin{array}{l}0.0017 \\
(0.9872)\end{array}$ & $\begin{array}{l}0.0109 \\
(0.9187)\end{array}$ & $\begin{array}{c}-0.2221 \\
(0.0477)\end{array}$ & $\begin{array}{l}0.0858 \\
(0.4523)\end{array}$ & $\begin{array}{c}-0.1282 \\
(0.2633)\end{array}$ & $\begin{array}{l}0.1528 \\
(0.1483)\end{array}$ & $\begin{array}{c}-0.3722 \\
(0.0003)\end{array}$ & & & & \\
\hline (10) & $\begin{array}{l}0.2332 \\
(0.0261)\end{array}$ & $\begin{array}{l}-0.1382 \\
(0.1915)\end{array}$ & $\begin{array}{l}0.0367 \\
(0.7295)\end{array}$ & $\begin{array}{l}-0.1565 \\
(0.1385)\end{array}$ & $\begin{array}{l}0.2041 \\
(0.0694)\end{array}$ & $\begin{array}{l}-0.0462 \\
(0.6857)\end{array}$ & $\begin{array}{l}0.1826 \\
(0.1096)\end{array}$ & $\begin{array}{l}0.2073 \\
(0.0487)\end{array}$ & $\begin{array}{c}-0.2464 \\
(0.0185)\end{array}$ & $\begin{array}{l}-0.1865 \\
(0.0767)\end{array}$ & & & \\
\hline (11) & $\begin{array}{l}-0.1146 \\
(0.2792)\end{array}$ & $\begin{array}{l}0.0557 \\
(0.5997)\end{array}$ & $\begin{array}{c}-0.0904 \\
(0.3940)\end{array}$ & $\begin{array}{l}0.0668 \\
(0.5292)\end{array}$ & $\begin{array}{l}0.0972 \\
(0.3909)\end{array}$ & $\begin{array}{l}-0.0247 \\
(0.8289)\end{array}$ & $\begin{array}{l}0.2010 \\
(0.0776)\end{array}$ & $\begin{array}{l}-0.0882 \\
(0.4058)\end{array}$ & $\begin{array}{c}-0.1504 \\
(0.1548)\end{array}$ & $\begin{array}{l}-0.1138 \\
(0.2828)\end{array}$ & $\begin{array}{l}-0.0753 \\
(0.4778)\end{array}$ & & \\
\hline (12) & $\begin{array}{l}0.0162 \\
(0.8789)\end{array}$ & $\begin{array}{c}-0.0989 \\
(0.3510)\end{array}$ & $\begin{array}{c}-0.0469 \\
(0.6590)\end{array}$ & $\begin{array}{l}0.0006 \\
(0.9956)\end{array}$ & $\begin{array}{l}0.1439 \\
(0.2029)\end{array}$ & $\begin{array}{l}0.2099 \\
(0.0634)\end{array}$ & $\begin{array}{l}-0.1323 \\
(0.2485)\end{array}$ & $\begin{array}{c}-0.0342 \\
(0.7471)\end{array}$ & $\begin{array}{l}-0.2024 \\
(0.0543)\end{array}$ & $\begin{array}{l}-0.1532 \\
(0.1471)\end{array}$ & $\begin{array}{c}-0.1014 \\
(0.3387)\end{array}$ & $\begin{array}{c}-0.0619 \\
(0.5600)\end{array}$ & \\
\hline $\begin{array}{l}\text { Mean* } \\
\text { Std Dev } \\
\text { Obs }\end{array}$ & $\begin{array}{l}55.5163 \\
52.5405 \\
92\end{array}$ & $\begin{array}{l}17.80 \\
35.20 \\
92\end{array}$ & $\begin{array}{l}42.10 \\
61.81 \\
92\end{array}$ & $\begin{array}{l}53.6058 \\
37.9837 \\
91\end{array}$ & $\begin{array}{l}27.8004 \\
22.8479 \\
81\end{array}$ & $\begin{array}{l}44.8231 \\
24.1077 \\
81\end{array}$ & $\begin{array}{l}20.2589 \\
25.1500 \\
80\end{array}$ & $\begin{array}{l}26.8391 \\
22.8479 \\
92\end{array}$ & $\begin{array}{l}0.2958 \\
0.4596 \\
71\end{array}$ & $\begin{array}{l}0.3239 \\
0.4713 \\
71\end{array}$ & $\begin{array}{l}0.1127 \\
0.3184 \\
71\end{array}$ & $\begin{array}{l}0.0845 \\
0.2801 \\
71\end{array}$ & $\begin{array}{l}0.0986 \\
0.3002 \\
71\end{array}$ \\
\hline
\end{tabular}

$P$ values in parentheses.

(1) Household income per capita

(2) Population per hospital bed

(3) Household's sewerage connection

(4) Household below poverty line

(5) Revenue from government

(6) Revenue from local tax

(7) City growth

(8) local government alone as sewerage service provider

(9) Central government alone as sewerage service provider

(10) Both local and central governments as sewerage service providers

(11) Parastatal and private sectors as sewerage service provider

(12) mix of all type of providers

* means for dummy variables of sewerage connections providers are the proportions of number observations of each category in total sample. 
Table 3-1 The OLS Regression of Child Mortality on Access to the Portable Water and other Variables: 1993

\begin{tabular}{|c|c|c|c|c|}
\hline \multirow[b]{2}{*}{ Variables } & \multicolumn{3}{|c|}{ Specification } & \multirow[b]{2}{*}{4} \\
\hline & 1 & 2 & 3 & \\
\hline Constant & $\begin{array}{l}200.94^{* * *} \\
(31.40)\end{array}$ & $\begin{array}{l}159.21^{* * *} \\
(38.37)\end{array}$ & $\begin{array}{l}124.22 * * * \\
(34.56)\end{array}$ & $\begin{array}{l}142.92^{* *} \\
(57.53)\end{array}$ \\
\hline Household income per capita & $\begin{array}{l}-0.24^{* * *} \\
(0.04)\end{array}$ & $\begin{array}{l}-0.17^{* * *} \\
(0.04)\end{array}$ & $\begin{array}{l}-0.12^{* * *} \\
(0.04)\end{array}$ & $\begin{array}{l}-0.07 \\
(0.08)\end{array}$ \\
\hline Population per hospital bed & $\begin{array}{l}0.16^{* *} \\
(0.07)\end{array}$ & $\begin{array}{l}0.11 * * \\
(0.05)\end{array}$ & $\begin{array}{l}0.06 \\
(0.06)\end{array}$ & $\begin{array}{l}0.10^{* *} \\
(0.04)\end{array}$ \\
\hline Access to potable water & $\begin{array}{l}-1.70^{* * *} \\
(0.32)\end{array}$ & $\begin{array}{l}-1.41 * * * \\
(0.37)\end{array}$ & $\begin{array}{l}-1.19 * * * \\
(0.34)\end{array}$ & $\begin{array}{l}-0.83^{* *} \\
(0.42)\end{array}$ \\
\hline Household below poverty line & & & $\begin{array}{l}0.47^{* *} \\
(0.21)\end{array}$ & $\begin{array}{c}0.41^{*} \\
(0.23) \\
:\end{array}$ \\
\hline Urban growth & & $\begin{array}{l}0.63^{* * *} \\
(0.22)\end{array}$ & $\begin{array}{l}0.79 * * * \\
(0.22)\end{array}$ & $\begin{array}{l}0.89 * * * \\
(0.24)\end{array}$ \\
\hline City revenue from central government & & & & $\begin{array}{l}-0.29 \\
(0.18)\end{array}$ \\
\hline City revenue from local tax & & & & $\begin{array}{l}-0.41^{* *} \\
(0.20)\end{array}$ \\
\hline \multicolumn{5}{|l|}{ Providers of city water services 1} \\
\hline Local government alone & & & & $\begin{array}{l}-41.71 * * \\
(21.03)\end{array}$ \\
\hline Central government alone & & & & $\begin{array}{l}-37.74 \\
(21.83)\end{array}$ \\
\hline Both local and central governments & & & & $\begin{array}{l}-18.40 \\
(24.66)\end{array}$ \\
\hline Mixture of type of providers & & & & $\begin{array}{l}-27.21 \\
(24.85)\end{array}$ \\
\hline $\mathrm{R}^{2}(\%)$ & 52.51 & 57.64 & 61.66 & 63.57 \\
\hline Number of observations & 92 & 92 & 81 & 67 \\
\hline
\end{tabular}

Note: Heteroskedasticity-consistent standard errors in parentheses.

1. The omitted category is parastatal and private providers

*** significant at $\mathrm{p}<0.01$

$* *$ significant at $\mathrm{p}<0.05$

* significant at $\mathrm{p}<0.10$. 
Table 3-2 The OLS Regression of Child Mortality on Sewerage Connection and other Variables: 1993

\begin{tabular}{|c|c|c|c|c|}
\hline \multirow[b]{2}{*}{ Variables } & \multicolumn{3}{|c|}{ Specification } & \multirow[b]{2}{*}{4} \\
\hline & 1 & 2 & 3 & \\
\hline Constant & $\begin{array}{l}89.41^{* * *} \\
(11.04)\end{array}$ & $\begin{array}{l}64.29 * * * \\
(13.88)\end{array}$ & $\begin{array}{l}43.15^{* * *} \\
(10.50)\end{array}$ & $\begin{array}{c}38.99 \\
(24.99)\end{array}$ \\
\hline Household income per capita & $\begin{array}{l}-0.12^{*} \\
(0.07)\end{array}$ & $\begin{array}{l}-0.07 \\
(0.06)\end{array}$ & $\begin{array}{l}-0.01 \\
(0.07)\end{array}$ & $\begin{array}{l}0.11 \\
(0.14)\end{array}$ \\
\hline Population per hospital bed & $\begin{array}{l}0.19 * * * \\
(0.06)\end{array}$ & $\begin{array}{l}0.13 * * * \\
(0.04)\end{array}$ & $\begin{array}{l}0.08 \\
(0.06)\end{array}$ & $\begin{array}{l}0.15 * * * \\
(0.05)\end{array}$ \\
\hline Sewerage connection & $\begin{array}{l}-0.76^{* * *} \\
(0.14)\end{array}$ & $\begin{array}{l}-0.60^{* * *} \\
(0.16)\end{array}$ & $\begin{array}{l}-0.52 * * * \\
(0.16)\end{array}$ & $\begin{array}{l}-0.47 * * \\
(0.24)\end{array}$ \\
\hline Household below poverty line & & & $\begin{array}{l}0.58 * * * \\
(0.18)\end{array}$ & $\begin{array}{l}0.54 \\
(0.43)\end{array}$ \\
\hline Urban growth & & $\begin{array}{l}0.67^{* * *} \\
(0.18)\end{array}$ & $\begin{array}{l}0.78 * * * \\
(0.27)\end{array}$ & $\begin{array}{l}0.55^{*} \\
(0.32)\end{array}$ \\
\hline City revenue from central government & & & & $\begin{array}{l}-0.10 \\
(0.19)\end{array}$ \\
\hline City revenue from local tax & & & & $\begin{array}{l}-0.29 \\
(0.22)\end{array}$ \\
\hline \multicolumn{5}{|l|}{ Providers of city sewerage system 1} \\
\hline Local government alone & & & & $\begin{array}{l}2.9 \\
(12.44)\end{array}$ \\
\hline Central government alone & & & & $\begin{array}{l}17.93 \\
(20.67)\end{array}$ \\
\hline Both local and central governments & & & & $\begin{array}{l}35.67^{* *} \\
(16.88)\end{array}$ \\
\hline Mixture of type of providers & & & & $\begin{array}{l}21.50 \\
(13.68)\end{array}$ \\
\hline $\mathbf{R}^{2}(\%)$ & 48.60 & 54.37 & 57.41 & 62.99 \\
\hline Number of observations & 91 & 91 & 80 & 58 \\
\hline
\end{tabular}

Note: Heteroskedasticity-consistent standard errors in parentheses.

1. The omitted category is parastatal and private providers

$* * *$ significant at $p<0.01$

$* *$ significant at $\mathrm{p}<0.05$

* significant at $\mathrm{p}<0.10$. 
Table 4. The Predicted Child Mortality by Percent of Access to Potable Water and Household Connections to Sewerage System: 1993

percent predicted child mortality rate Access water equation $\quad$ Sewerage connection equation

\begin{tabular}{lll}
\hline 10 & 109.98 & 97.73 \\
20 & 101.64 & 93.03 \\
30 & 93.30 & 88.33 \\
40 & 84.97 & 83.63 \\
50 & 76.63 & 78.93 \\
60 & 68.29 & 74.23 \\
70 & 59.95 & 69.53 \\
80 & 51.61 & 64.83 \\
90 & 43.28 & 60.13 \\
95 & 39.11 & 57.78 \\
100 & 34.94 & 55.43 \\
& & $77.24^{* *}$
\end{tabular}

Note: The predicted child mortality rates (per 1,000) are calculated from column 4 of Table 3-1 and Table 3-2 respectively, holding all other variables constant at their mean values, and with local government as water service provider in water access equation (Table 3-1) and both local and central governments as sewerage system provider in sewerage equation (Table 3-2).

* The mean percentage of access to potable water is 86.89 .

**The mean percentage of sewerage connection is 51.58 . 
Table 5-1 Two-stage Least Squares (2SLS) Estimations of Child Mortality on Access to Portable Water and Sewerage Connection: 1993

\begin{tabular}{lll}
\hline Variables & potable water access & sewerage connection \\
\hline & (Standard errors in parentheses) \\
& $207.78^{* * *}$ & $111.80^{* * *}$ \\
Constant & $(66.40)$ & $(19.87)$ \\
& -0.11 & 0.09 \\
Household income per capita & $(0.20)$ & $(0.21)$ \\
& $0.16^{*}$ & 0.13 \\
Population per hospital bed & $(0.08)$ & $(0.08)$ \\
& $-2.54^{* * *}$ & $-1.19^{* * *}$ \\
Access to services & $(0.75)$ & $(0.32)$ \\
& 34.07 & 40.40 \\
R2(\%) & 59 & 51 \\
Number of observations & & \\
\hline
\end{tabular}

Note: First-stage $\mathrm{R}^{2}$ for potable water access: $38.95 \%$. Instruments: a constant, household income per capita, percentage of population under poverty line, urban growth, local government has its own autonomy in setting services use fees, type of water service providers, percentage of local revenue from central government transfers, and percentage of local revenue from local tax. First-stage $\mathrm{R}^{2}$ for household sewerage connection is $53.26 \%$. Instruments: a constant, household income per capita, percentage of population under poverty line, urban growth, local government has its own autonomy in setting services use fees, type of sewerage connection service providers, percentage of local revenue from central government transfers, and percentage of local revenue from local tax.

*** significant at $\mathrm{p}<0.01$

$* *$ significant at $p<0.05$

* significant at $\mathrm{p}<0.10$. 
Table 5-2 The OLS Regression of Child Mortality on Access to the Portable Water and other Variables: 1993 Extended example

\begin{tabular}{|c|c|c|c|c|}
\hline \multirow[b]{2}{*}{ Variables } & \multicolumn{3}{|c|}{ Specification } & \multirow[b]{2}{*}{4} \\
\hline & 1 & 2 & 3 & \\
\hline Constant & $\begin{array}{l}208.34^{* * *} \\
(26.11)\end{array}$ & $\begin{array}{l}186.66 * * * \\
(31.89)\end{array}$ & $\begin{array}{l}149.30 * * * \\
(32.27)\end{array}$ & $\begin{array}{l}224.9 * * * \\
(40.03)\end{array}$ \\
\hline GDP per capita & $\begin{array}{l}-0.15^{* * *} \\
(0.02)\end{array}$ & $\begin{array}{l}-0.12 * * * \\
(0.03)\end{array}$ & $\begin{array}{l}-0.10 * * \\
(0.05)\end{array}$ & $\begin{array}{l}-0.10 \\
(0.10)\end{array}$ \\
\hline Population per hospital bed & $\begin{array}{l}0.16^{* * *} \\
(0.06)\end{array}$ & $\begin{array}{l}0.14^{* * *} \\
(0.05)\end{array}$ & $\begin{array}{l}0.10 \\
(0.08)\end{array}$ & $\begin{array}{l}0.15^{* *} \\
(0.07)\end{array}$ \\
\hline Access to potable water & $\begin{array}{l}-1.77 * * * \\
(0.26)\end{array}$ & $\begin{array}{l}-1.61^{* * *} \\
(0.30)\end{array}$ & $\begin{array}{l}-1.41^{* * *} \\
(0.30)\end{array}$ & $\begin{array}{l}-1.41 * * * \\
(0.35)\end{array}$ \\
\hline Household below poverty line & & & $\begin{array}{l}0.63^{* * *} \\
(0.21)\end{array}$ & $\begin{array}{l}0.49 * * \\
(0.25)\end{array}$ \\
\hline Urban growth & & $\begin{array}{l}0.29 \\
(0.23)\end{array}$ & $\begin{array}{l}0.36 \\
(0.25)\end{array}$ & $\begin{array}{l}0.27 \\
(0.22)\end{array}$ \\
\hline City revenue from central government & & & & $\begin{array}{l}-0.66^{* * *} \\
(0.24)\end{array}$ \\
\hline City revenue from local tax & & & & $\begin{array}{l}-0.54^{* *} \\
(0.25)\end{array}$ \\
\hline \multicolumn{5}{|l|}{ Providers of city water services 1} \\
\hline Local government alone & & & & $\begin{array}{l}-42.48 * * \\
(16.04)\end{array}$ \\
\hline Central government alone & & & & $\begin{array}{l}-31.88 * \\
(18.47)\end{array}$ \\
\hline Both local and central governments & & & & $\begin{array}{l}-8.26 \\
(20.93)\end{array}$ \\
\hline Mixture of type of providers & & & & $\begin{array}{l}-36.85^{* *} \\
(17.44)\end{array}$ \\
\hline $\mathbf{R}^{2}(\%)$ & 50.30 & 51.92 & 51.85 & 57.53 \\
\hline Number of observations & 140 & 140 & 115 & 91 \\
\hline
\end{tabular}

Note: Heteroskedasticity-consistent standard errors in parentheses.

1. The omitted category is parastatal and private providers

*** significant at $\mathrm{p}<0.01$

** significant at $\mathrm{p}<0.05$

*significant at $\mathrm{p}<0.10$. 
Table 5-3 The OLS Regression of Child Mortality on Sewerage Connections and other Variables: 1993 Extended sample

\begin{tabular}{|c|c|c|c|c|}
\hline \multirow[b]{2}{*}{ Variables } & \multicolumn{3}{|c|}{ Specification } & \multirow[b]{2}{*}{4} \\
\hline & 1 & 2 & 3 & \\
\hline Constant & $\begin{array}{l}98.11 * * * \\
(10.19)\end{array}$ & $\begin{array}{l}86.82 * * * \\
(16.15)\end{array}$ & $\begin{array}{l}59.28 * * * \\
(16.53)\end{array}$ & $\begin{array}{c}84.0^{* * *} \\
(32.36)\end{array}$ \\
\hline GDP per capita & $\begin{array}{l}-0.10^{* * * *} \\
(0.03)\end{array}$ & $\begin{array}{l}-0.09^{* * * *} \\
(0.03)\end{array}$ & $\begin{array}{l}-0.04 \\
(0.07)\end{array}$ & $\begin{array}{l}-0.02 \\
(0.12)\end{array}$ \\
\hline Population per hospital bed & $\begin{array}{l}0.17^{* * *} \\
(0.04)\end{array}$ & $\begin{array}{l}0.15^{* * *} \\
(0.04)\end{array}$ & $\begin{array}{l}0.11 \\
(0.07)\end{array}$ & $\begin{array}{l}0.15^{*} \\
(0.08)\end{array}$ \\
\hline Sewerage connection & $\begin{array}{l}-0.79 * * * \\
(0.13)\end{array}$ & $\begin{array}{l}-0.71 * * * \\
(0.17)\end{array}$ & $\begin{array}{l}-0.65 * * * \\
(0.19)\end{array}$ & $\begin{array}{l}-0.76^{* * *} \\
(0.24)\end{array}$ \\
\hline Household below poverty line & & & $\begin{array}{l}0.80 * * * \\
(0.24)\end{array}$ & $\begin{array}{l}0.74 * * \\
(0.33)\end{array}$ \\
\hline Urban growth & & $\begin{array}{l}0.24 \\
(0.28)\end{array}$ & $\begin{array}{l}0.29 \\
(0.29)\end{array}$ & $\begin{array}{l}0.15 \\
(0.28)\end{array}$ \\
\hline City revenue from central government & & & & $\begin{array}{l}-0.56^{* *} \\
(0.24)\end{array}$ \\
\hline City revenue from local tax & & & & $\begin{array}{l}-0.37 \\
(0.28)\end{array}$ \\
\hline Providers of city sewerage system 1 & & & & \\
\hline Local government alone & & & & $\begin{array}{c}19.24 \\
(16.89)\end{array}$ \\
\hline Central government alone & & . & & $\begin{array}{l}18.57 \\
(21.65)\end{array}$ \\
\hline Both local and central governments & & & & $\begin{array}{l}38.74^{*} \\
(21.42)\end{array}$ \\
\hline Mixture of type of providers & & & & $\begin{array}{l}16.02 \\
(17.94)\end{array}$ \\
\hline $\begin{array}{l}\mathbf{R}^{2}(\%) \\
\text { Number of observations }\end{array}$ & 45.68 & 46.70 & 47.28 & 51.83 \\
\hline Number of observations & 137 & 137 & 113 & 82 \\
\hline
\end{tabular}

Note: Heteroskedasticity-consistent standard errors in parentheses.

1. The omitted category is parastatal and private providers

*** significant at $\mathrm{p}<0.01$

** significant at $\mathrm{p}<0.05$

* significant at $\mathrm{p}<0.10$. 
Table 5-4 The OLS Regression of Child Mortality on Access to the Portable Water (Sewerage Connection), other Variables, and Regional Dummies: 1993

\begin{tabular}{|c|c|c|}
\hline \multirow[b]{2}{*}{ Variables } & \multicolumn{2}{|c|}{ Specification } \\
\hline & water access equation & Sewerage connection equation \\
\hline Constant & $\begin{array}{l}201.16^{* * *} \\
(52.78)\end{array}$ & $\begin{array}{l}92.50 * * * \\
(23.07)\end{array}$ \\
\hline Household income per capita & $\begin{array}{l}-0.12^{* *} \\
(0.06)\end{array}$ & $\begin{array}{l}0.02 \\
(0.11)\end{array}$ \\
\hline Population per hospital bed & $\begin{array}{l}0.13^{* * *} \\
(0.04)\end{array}$ & $\begin{array}{l}0.20^{* * *} \\
(0.03)\end{array}$ \\
\hline Access to potable water (Sewerage connection) & $\begin{array}{l}-1.03^{* * * *} \\
(0.38)\end{array}$ & $\begin{array}{l}-0.59^{* * *} \\
(0.18)\end{array}$ \\
\hline Household below poverty line & $\begin{array}{l}0.33^{*} \\
(0.19)\end{array}$ & $\begin{array}{l}0.39 \\
(0.32)\end{array}$ \\
\hline Urban growth & $\begin{array}{l}0.26 \\
(0.29)\end{array}$ & $\begin{array}{l}-0.02 \\
(0.32)\end{array}$ \\
\hline City revenue from central government & $\begin{array}{l}-0.36^{*} \\
(0.20)\end{array}$ & $\begin{array}{l}-0.05 \\
(0.13)\end{array}$ \\
\hline City revenue from local tax & $\begin{array}{l}-0.52^{* *} \\
(0.20)\end{array}$ & $\begin{array}{l}-0.32^{*} \\
(0.17)\end{array}$ \\
\hline \multicolumn{3}{|l|}{ Providers of city water (sewerage) services 1} \\
\hline Local government alone & $\begin{array}{l}-20.35 \\
(15.78)\end{array}$ & $\begin{array}{l}18.30 \\
(13.40)\end{array}$ \\
\hline Central government alone & $\begin{array}{l}-21.96 \\
(16.18)\end{array}$ & $\begin{array}{l}18.96 \\
(17.48)\end{array}$ \\
\hline Both local and central governments & $\begin{array}{l}-20.59 \\
(18.49)\end{array}$ & $\begin{array}{l}16.46 \\
(18.18)\end{array}$ \\
\hline Mixture of type of providers & $\begin{array}{l}-19.19 \\
(20.84)\end{array}$ & $\begin{array}{l}13.29 \\
(13.56)\end{array}$ \\
\hline \multicolumn{3}{|l|}{ Region 2} \\
\hline$\overline{\text { European and developed countries }}$ & $\begin{array}{l}-39.77^{* * *} \\
(13.10)\end{array}$ & $\begin{array}{l}-43.35^{* * * *} \\
(14.43)\end{array}$ \\
\hline Latin American countries & $\begin{array}{l}-37.36^{* * *} \\
(11.54)\end{array}$ & $\begin{array}{l}-30.88 * * * \\
(10.55)\end{array}$ \\
\hline Asian countries & $\begin{array}{l}-49.58 * * * \\
(10.85)\end{array}$ & $\begin{array}{l}-67.21^{* * *} \\
(12.52)\end{array}$ \\
\hline $\mathrm{R}^{2}(\%)$ & 73.94 & 80.11 \\
\hline Number of observations & 67 & 58 \\
\hline
\end{tabular}

Note: Heteroskedasticity-consistent standard errors in parentheses.

1. The omitted category is parastatal and private providers.

2. The omitted category is African and Middle East countries.

$* * *$ significant at $p<0.01$

** significant at $p<0.05$

* significant at $\mathrm{p}<0.10$. 
Abidjan (Cote d'Ivoire), Amman (Jordan), Amsterdam (Netherlands), Arusha (Tanzania), Assiout (Egypt), Atlanta (United States of America), Baku (Azerbaijan), Bandung (Indonesia), Bangalore (India), Banjarmasin (Indonesia), Barbados (Barbados), Bedfordshire (United Kingdom), Bobo-Dioulasso (Burkina Faso), Bogota (Colombia), Brasilia (Brazil), Bratislava (Slovak Republic), Brest (France), Budapest (Hungary), Bujumbura (Burundi), Bulawayo (Zimbabwe), Cairo (Egypt), Chennai (India), Chisinau (Moldova), Chittagong (Bangladesh), Colombo (Sri Lanka), Copenhagen (Denmark), Cotonou (Benin), Cuenca (Ecuador), Curitiba (Brazil), Dakar (Senegal), Dar es Salaam (Tanzania), Delhi (India), Djibouti (Djibouti), Foshan (China), Freetown (Sierra Leone), Gharbeya (Egypt), Guatemala city (Guatemala), Guayaquil (Ecuador), Gulbarga (India), Harare (Zimbabwe), Hefei (China), Hubli-Dharbad (India), Ibadan (Nigeria), Jakarta (Indonesia), Kaoloack (Senegal), Koper (Slovenia), Kostroma (Russian Federation), La Paz (Bolivia), Labe (Guinee), Lahore (Pakistan), Libreville (Gabon), Lima (Peru), Ljubljana (Slovenia), Lucknow (India), Maribor (Slovenia), Medan (Indonesia), Melbourne (Australia), Moscow (Russian Federation), Bombay (India), Mysore (India), Niamey (Niger), Nizhny Novgorod (Russian Federation), Nouakchott (Mauritania), Novgorod (Russian Federation), Onitsha (Nigeria), Ouagadougou (Burkina Faso), Paris (France), Porto Novo (Benin), Rabat (Maroc), Recife (Brazil), Rio de Janeiro (Brazil), Ryazan (Russian Federation), San Miguel (El Salvador), San Salvador (El Salvador), Sana'a (Yemen), Santa Ana (El Salvador), Santiago (Chile), Seattle (United States of America), Semarang (Indonesia), Stockholm (Sweden), Surabaya (Indonesia), Tambacounda (Senegal), Tangail (Bangladesh), Toronto (Canada), Tumkur (India), Tunis (Tunisia), Ulaanbaatar (Mongolia), Varanasi (India), Windhoek (Namibia), Yerevan (Armenia), Zagreb (Croatia), Ziguinchor (Senegal).

Appendix 2. Additional 48 Cities in Extended Sample

Addis Aba (Ethiopia), Almaty (Kazakhsta), Amman (Jordan), Antananar (Madagasca), Athens (Greece), Bamako (Mali), Bangui (Central Africa), Bhiwandi (India), Cajamarca (Peru), Cardiff (United Kingdom), Dhaka (Bangladesh), Donetsk (Ukraine), Duisburg (Germany), Dunkerque (France), Erfurt (Germany), Freiburg (Germany), Gaborone (Botswana), George To (Guyana), Jinja (Uganda), Kampala (Uganda) Khartoum (Sudan), Kigali (Rwanda), Koeln (Germany), Koudougou (Burkina Faso), Leipzig (Germany), Lilongwe (Malawi), Lome (Togo), Lyon (France), Mbale (Uganda), Mbarara (Uganda), Mbeya (Tanzania), Mwanza (Tanzania), Mzuzu (Malawi), Nairobi (Kenya), N'Djamena (Chad), Pokhara(Nepal), Prague (Czech Rep), Quito (Ecuador), Riga (Latvia), Seychelle (Seychelle), Sofia (Bulgaria), Suva (Fiji), Tallin (Estonia), Tbilisi (Georgia), Tirana (Albania), Trujillo (Peru),Vilnius (Lithuania), Wiesbaden (Germany). 
Appendix 3 City-level data: 1993

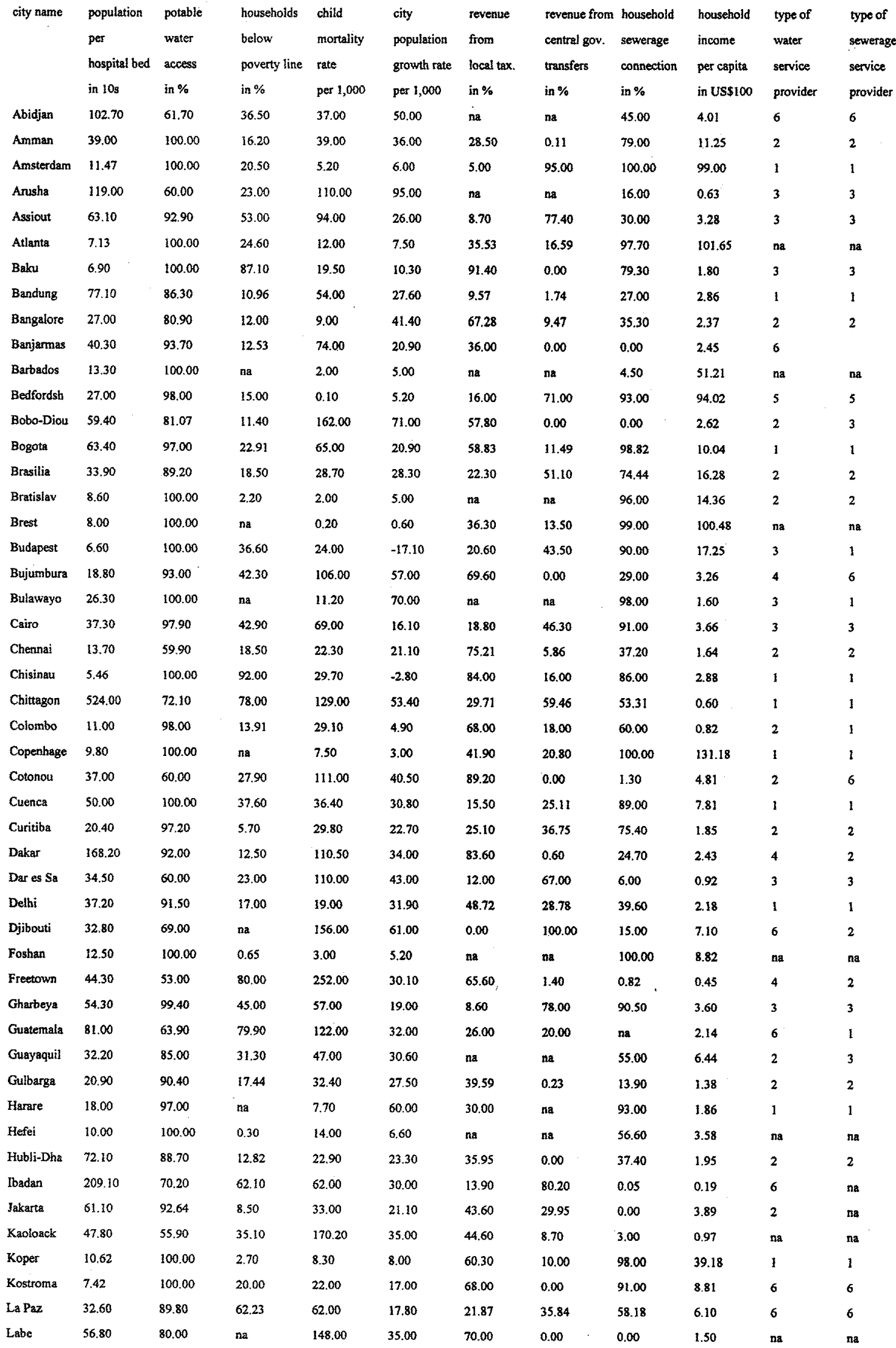




\begin{tabular}{|c|c|c|c|c|c|c|c|c|c|c|}
\hline city name & $\begin{array}{l}\text { population } \\
\text { per } \\
\text { hospital bed } \\
\text { in } 10 \text { s }\end{array}$ & $\begin{array}{l}\text { potable } \\
\text { water } \\
\text { access } \\
\text { in } \%\end{array}$ & $\begin{array}{l}\text { households } \\
\text { below } \\
\text { poverty line } \\
\text { in } \%\end{array}$ & $\begin{array}{l}\text { child } \\
\text { mortality } \\
\text { rate } \\
\text { per } 1,000\end{array}$ & $\begin{array}{l}\text { city } \\
\text { population } \\
\text { growth rate } \\
\text { per } 1,000\end{array}$ & $\begin{array}{l}\text { revenue } \\
\text { from } \\
\text { local tax } \\
\text { in \% }\end{array}$ & $\begin{array}{l}\text { revenue from } \\
\text { central gov. } \\
\text { transfers } \\
\text { in } \%\end{array}$ & $\begin{array}{l}\text { household } \\
\text { sewerage } \\
\text { connection } \\
\text { in } \%\end{array}$ & $\begin{array}{l}\text { household } \\
\text { income } \\
\text { per capita } \\
\text { in US\$100 }\end{array}$ & $\begin{array}{l}\text { type of } \\
\text { water } \\
\text { service } \\
\text { provider }\end{array}$ \\
\hline Lahore & 50.90 & 90.00 & -30.00 & 91.90 & 35.90 & 40.18 & 12.02 & 74.00 & 3.67 & na \\
\hline Librevill & 31.10 & 100.00 & na & 114.00 & 47.00 & 96.60 & 0.00 & 0.00 & 17.06 & 4 \\
\hline Lima & 19.83 & 86.90 & 29.40 & 24.00 & 27.00 & 64.40 & 11.00 & 68.80 & 3.57 & 4 \\
\hline Ljubljana & 3.60 & 100.00 & 3.60 & 8.30 & 18.00 & 87.40 & 0.00 & 99.00 & 37.89 & 1 \\
\hline Lucknow & 46.00 & 88.20 & 22.00 & 41.70 & 40.40 & 34.50 & 30.88 & 30.00 & 1.33 & 1 \\
\hline Maribor & 4.75 & 99.50 & 14.40 & 8.10 & -2.00 & 68.00 & 19.00 & 58.00 & 28.06 & 1 \\
\hline Medan & 25.60 & 93.75 & 8.70 & 50.00 & 19.50 & 28.64 & 26.41 & 19.00 & 2.54 & 2 \\
\hline Melbourne & 31.20 & 100.00 & na & 7.00 & 11.00 & 49.00 & 7.00 & 98.90 & 86.55 & 2 \\
\hline Moscow & 8.01 & 100.00 & 15.00 & 20.70 & -9.00 & 76.70 & 9.90 & 99.70 & 10.35 & 6 \\
\hline Mumbai (B & 39.80 & 96.40 & 17.00 & 17.50 & 20.40 & 42.65 & 0.94 & 51.40 & 1.96 & 1 \\
\hline Mysore & 15.60 & 89.90 & 5.51 & 29.20 & 36.40 & 67.23 & 0.94 & 60.00 & 2.25 & 2 \\
\hline Niamey & 52.20 & 76.80 & 42.00 & 111.00 & 48.00 & 40.15 & 3.66 & 0.00 & 1.51 & 4 \\
\hline Nizhny No & 6.42 & 100.00 & 24.00 & 20.00 & -29.00 & 69.00 & 0.00 & 94.70 & 9.24 & 6 \\
\hline Nouakchot & 108.40 & 68.00 & 25.00 & 120.00 & 80.00 & 80.90 & 0.00 & 4.00 & 2.59 & 2 \\
\hline Novgorod & 5.87 & 100.00 & 18.00 & 26.00 & 0.00 & 64.90 & 0.00 & 96.00 & 9.09 & 2 \\
\hline Onitsha & 10.99 & 95.00 & 87.00 & 63.00 & 47.00 & 12.90 & 77.10 & 0.00 & 0.53 & 6 \\
\hline Ouagadoug & 83.30 & 74.70 & 11.40 & 150.00 & 94.00 & 63.46 & 0,00 & 0.00 & 2.87 & 2 \\
\hline Paris & 11.70 & 100.00 & na & 9.10 & 5.70 & $41 . \infty$ & 15.00 & 98.00 & 60.62 & ла \\
\hline Porto Noy & 71.40 & 76.00 & 31.70 & 110.00 & 23.10 & 58.30 & 1.57 & 1.40 & 2.22 & 2 \\
\hline Rabat & 36.50 & 100.00 & 7.00 & 60.00 & 37.00 & 35.60 & 0.00 & 95.00 & 11.55 & 1 \\
\hline Recife & 13.10 & 94.70 & 34.80 & 38.50 & 6.90 & 21.10 & 42.00 & 37.50 & 0.88 & 2 \\
\hline Rio de Ja & 16.50 & 97.60 & 18.50 & 31.80 & 6.70 & 26.81 & 20.15 & 87.10 & 19.57 & 3 \\
\hline Ryezan : & 7.42 & 100.00 & 36.00 & 20.00 & 20.00 & 73.30 & 6.70 & 91.50 & 7.27 & 1 \\
\hline San Migue & 24.90 & 56.20 & 50.00 & 46.00 & 35.10 & 26.00 & 7.00 & 46.00 & 5.52 & 2 \\
\hline San Salva & 25.90 & 90.50 & 40.10 & 45.00 & 39.10 & 41.00 & 8.00 & 80.10 & 6.71 & 2 \\
\hline Sana'a & 52.00 & 60.00 & $\mathbf{n z}$ & 122.00 & 88.30 & na & na & 12.00 & 0.26 & 6 \\
\hline Santa Ana & 22.50 & 82.20 & 49.50 & 46.00 & 16.70 & 59.00 & 17.00 & 56.60 & $5.31^{\circ}$ & 2 \\
\hline Santiago & 31.00 & 97,80 & 21.60 & 17.00 & 18.00 & $\mathrm{na}$ & na & 91.70 & 12.35 & 6 \\
\hline Seattle & 16.95 & 100.00 & 7.40 & 12.00 & 20.40 & 37.00 & 8.40 & 99.50 & 140.39 & na \\
\hline Semarang & 46.50 & 88.17 & 6.80 & 53.00 & 15.10 & 14.35 & 32.80 & 0.00 & 2.29 & 1 \\
\hline Stockholm & 9.00 & 100.00 & 0.30 & 5.80 & 8.60 & 42.00 & 13.00 & 100.00 & 131.86 & 1 \\
\hline Surabaya & 51.60 & 99.03 & 4.50 & 52.00 & 17.30 & 12.39 & 21.00 & 0.00 & 3.17 & 1 \\
\hline Tambacoun & 57.10 & 12.90 & 44.00 & 182.70 & 42.00 & 67.60 & 0.00 & 2.40 & 1.53 & na \\
\hline Tangail & 14.30 & 51.00 & 37.00 & 106.00 & 33.70 & 42.93 & 10.39 & na & 0.32 & 1 \\
\hline Toronto & 17.70 & 100,00 & 23.00 & 1.80 & 7.50 & 38.00 & 29.00 & 99.50 & 165.98 & 1 \\
\hline Tumkur & 48.60 & 86.20 & 24.60 & 29.20 & 40.40 & 64.24 & 2.53 & 0.00 & 1.26 & 1 \\
\hline Tunis & 36.00 & 96.30 & 6.30 & 43.00 & 27.00 & 35.00 & 39.00 & 72.70 & 7.75 & 2 \\
\hline Ulaanbaat & 7.80 & 49.00 & 12.40 & 11.30 & 17.00 & 79.20 & 0.00 & 51.00 & 0.69 & 1 \\
\hline Varanasi & 37.20 & 84.50 & 28.27 & 43.10 & 22.70 & 24.28 & 49.34 & 40.65 & 0.85 & 2 \\
\hline Windhoek & 9.77 & 98.00 & 30.00 & 87.00 & 54.40 & 16.00 & 0.00 & 75.00 & 15.66 & 1 \\
\hline Yerevan & 9.80 & 98.00 & 80.00 & 50.00 & -0.20 & na & na & 93.40 & 1.22 & 1 \\
\hline Zagreb & 11,30 & 90.00 & 6.10 & 10.20 & 8.70 & 53.10 & 19.10 & 80.00 & 11.49 & 3 \\
\hline Ziguincho & 132.30 & 29.50 & 26.60 & 194.90 & 49.00 & 52.70 & 0.00 & 1.90 & 1.02 & na \\
\hline
\end{tabular}

Source: UNCHS Global Urban Indicators Database, 1993.

Note: $n a=$ data not available

Coding for type of providers: (1) local govemment only, (2) national and regional government only, (3) Both local, regional, and national government, (4) parastatal, (5) private, (6) mix of public and private providers. 


\section{References}

Auclair, Christine. 1998. Urban Indicators Proramme. Paper presented at the World Bank Seminar.

Briscoe, John. 1992. "Poverty and Water Supply: How to Move Forward." Finance \& Development. Vol.29(4): 16-19.

Brocherhoff, Martin and Ellen Brennan. 1998. "The Poverty of Cities in Developing Regions." Population and Development Review 24 (1): 75-114.

Cheema, Shabbir. 1992. "Issues in Urban management," in Harris 1992: 110-112.

Demery, Lionel and Lyn Squire. 1996. "Macroeconomic Adjustment and Poverty in African: An Emerging Picture." The World Bank Research Observer. Vol 11(1):39-59.

Feachem, R. 1981. "The Water and Sanitation Decade." Journal of Tropical Medicine and Hygiene. Vol 84 (2).

Flood Joe. 1997. "Indicators Programme 1994-96: Report Prepared for the UNCHS for Human Settlements." United Nations Centre for Human Settlements (Habitat).

Frankel, Jeffrey and David Romer. 1999. "Does Trade Cause Growth." The American Economic Review. Vol.89 (3): 379-399.

Harrison, Paul. 1982. Inside the Third World. Harmondsworth. UK: Penguin.

Harpham, Trudy, Tim Lusty, and Patrick Vaughan. 1988. In the Shadow of the City: Community Health and the Urban Poor. Oxford: Oxford University Press.

Gilber, Alan. 1993. "Third World Cities: The Changing National Settlement System," Urban Studies 30, No. 4/5:721-740.

Kennedy, Paul. 1993. Preparing for the Twenty-first Century. New York: Random House.

McCarney, Patricia, Mohamed Halfani, and Alfredo Rodriguez. 1995. "Towards an Understanding of Governance: The Emergence of an Idea and Its Implications for Urban Research in Developing Countries." In Richard Stren 1995. Perspectives on the City. Volume 4. Toronto: University of Toronto, Centre for Urban and Community Studies. 
Merrick Thomas W. 1985. "The Effect of Piped Water on Early Childhood Mortality in Urban Brazil, 1970 to 1976". Demography Vol. 22 (1)1-24.

Mills, Edwin S. and Charles M. Becker. 1986. Studies in Indian Urban Development. Washington, DC: The World Bank.

Minujin, Akberti. 1995. "Squeezed: The Middle Class in Latin America," Environment and Urbanization 7. No. 2: 153-165.

Patel, M. 1981. "Modelling Determinants of Health." International Journal of Epidemiology. Vol. 10(3).

Prudh'homme, Remy. 1994. "On the Economic Role of Cities," paper presented at the conference on Cities and the New Global Economy, Organized by Government of Australia and OECD, 20-23 November, Melbourne.

Puffer, R.R. and C.V. Serrano. 1973. Patterns of Morality in Childhood. Washington, D.C.: Pan American Health Organization.

Schultz, T. P. 1980. Interpretation of Relations among Mortality, Economics of the Household, and the Health Environment. In Proceedings of the Meeting on Socioeconomic Determinants and Consequences of Mortality, Mexico City, June 19-25, 1979, Geneva: World Health Organization.

Stephens, Carolyn. 1996. "Healthy Cities or Unhealth Islands? The Health and Social Implications of Urban Inequality," Environment and Urbanization 8. No.(2):930 .

Stren, Richard. 1995. Perspectives on the City. Volume 4. Toronto: University of Toronto, Centre for Urban and Community Studies.

Timaeus, Ian M. and Louisiana Lush. 1995. "Intra-urban Differentials in Child Health." Health Transition Review 5. No.2:163-190.

United Nations Center for Human Settlements (UNCHS). 1997. "Monitoring Progress on Implementation of the Habitat Agenda One Year After Habitat II." Habitate Debate. Vol. 3 (No.3).

Werna, Edmundo. 1996. "United Nations Agencies' Urban Policies and Health." In Sarah Atkinson, Jacob Songsore, and Edmundo Werna (eds.). Urban Health Research in Developing Countries: Implications for Policy, pp.11-30. New York: Oxford University Press.

White, Halbert. 1980. "A Heteroscedasticity-Consistent Covariance Matrix Estimator and a Direct Test for Heteroscedasticity." Econometrica 48:817-38. 
World Bank. 1990. World Development Report 1990. New York: Oxford University Press.

World Bank. 1998. Reducing Poverty in India: Options for More Effective Public Services. Washington DC: The World Bank.

World Health Organization. 1978. "Main Findings of the Comparative Study of Social and Biological Effects on Perinatal Mortality." World Health Statistics 31(3). 
Policy Research Working Paper Seiss

\begin{tabular}{|c|c|c|c|c|}
\hline & Title & Author & Date & $\begin{array}{l}\text { Contact } \\
\text { for paper }\end{array}$ \\
\hline WPS2252 & $\begin{array}{l}\text { Productivity Growth, Capital } \\
\text { Accumulation, and the Banking } \\
\text { Sector: Some Lessons from Malaysia }\end{array}$ & $\begin{array}{l}\text { Ejaz Ghani } \\
\text { Vivek Suri }\end{array}$ & December 1999 & $\begin{array}{l}\text { N. Mensah } \\
80546\end{array}$ \\
\hline WPS2253 & $\begin{array}{l}\text { Revenue Recycling and the Welfare } \\
\text { Effects of Road Pricing }\end{array}$ & $\begin{array}{l}\text { Ian W. H. Parry } \\
\text { Antonio Miguel R. Bento }\end{array}$ & December 1999 & $\begin{array}{l}\text { R. Yazigi } \\
37176\end{array}$ \\
\hline WPS2254 & $\begin{array}{l}\text { Does "Grease Money" Speed Up } \\
\text { the Wheels of Commerce? }\end{array}$ & $\begin{array}{l}\text { Daniel Kaufmann } \\
\text { Shang-Jin Wei }\end{array}$ & December 1999 & $\begin{array}{l}\text { H. Sladovich } \\
37698\end{array}$ \\
\hline WPS2255 & $\begin{array}{l}\text { Risk and Efficiency in East Asian } \\
\text { Banks }\end{array}$ & Luc Laeven & December 1999 & $\begin{array}{l}\text { R. Vo } \\
33722\end{array}$ \\
\hline WPS2256 & $\begin{array}{l}\text { Geographical Disadvantage: } \\
\text { A Heckscher-Ohlin-von Thunen } \\
\text { Model of International Specialization }\end{array}$ & $\begin{array}{l}\text { Anthony J. Venables } \\
\text { Nuno Limão }\end{array}$ & December 1999 & $\begin{array}{l}\text { L. Tabada } \\
36896\end{array}$ \\
\hline WPS2257 & $\begin{array}{l}\text { Infrastructure, Geographical } \\
\text { Disadvantage, and Transport Costs }\end{array}$ & $\begin{array}{l}\text { Nuno Limão } \\
\text { Anthony J. Venables }\end{array}$ & December 1999 & $\begin{array}{l}\text { L. Tabada } \\
36896\end{array}$ \\
\hline WPS2258 & $\begin{array}{l}\text { Market Access Bargaining in the } \\
\text { Uruguay Round: Rigid or Relaxed } \\
\text { Reciprocity? }\end{array}$ & $\begin{array}{l}\text { J. Michael Finger } \\
\text { Ulrich Reincke } \\
\text { Adriana Castro }\end{array}$ & December 1999 & $\begin{array}{l}\text { L. Tabada } \\
36896\end{array}$ \\
\hline WPS2259 & $\begin{array}{l}\text { Predicting Currency Fluctuations } \\
\text { and Crises: Do Resident Firms } \\
\text { Have an Informational Advantage? }\end{array}$ & $\begin{array}{l}\text { Daniel Kaufmann } \\
\text { Gil Mehrez } \\
\text { Sergio Schmukler }\end{array}$ & December 1999 & $\begin{array}{l}\text { E. Khine } \\
37471\end{array}$ \\
\hline WPS2260 & $\begin{array}{l}\text { Regional Integration Agreements: } \\
\text { A Force for Convergence or } \\
\text { Divergence? }\end{array}$ & Anthony J. Venables & December 1999 & $\begin{array}{l}\text { L. Tabada } \\
36896\end{array}$ \\
\hline WPS2261 & $\begin{array}{l}\text { Is Knowledge Shared within } \\
\text { Households? }\end{array}$ & $\begin{array}{l}\text { Kaushik Basu } \\
\text { Ambar Narayan } \\
\text { Martin Ravallion }\end{array}$ & December 1999 & $\begin{array}{l}\text { M. Mason } \\
30809\end{array}$ \\
\hline WPS2262 & $\begin{array}{l}\text { How Inadequate Provision of Public } \\
\text { Infrastructure and Services Affects } \\
\text { Private Investment }\end{array}$ & $\begin{array}{l}\text { Ritva Reinikka } \\
\text { Jakob Svensson }\end{array}$ & December 1999 & $\begin{array}{l}\text { H. Sladovich } \\
37698\end{array}$ \\
\hline WPS2263 & $\begin{array}{l}\text { When Is Growth Pro-Poor? Evidence } \\
\text { from the Diverse Experiences of } \\
\text { India's States }\end{array}$ & $\begin{array}{l}\text { Martin Ravallion } \\
\text { Gaurav Datt }\end{array}$ & December 1999 & $\begin{array}{l}\text { J. Israel } \\
85117\end{array}$ \\
\hline WPS2264 & $\begin{array}{l}\text { Do More Unequal Countries } \\
\text { Redistribute More? Does the Median } \\
\text { Voter Hypothesis Hold? }\end{array}$ & Branko Milanovic & December 1999 & $\begin{array}{l}\text { P. Sader } \\
33902\end{array}$ \\
\hline
\end{tabular}




\section{Pollcy Research Working Paper Series}

\begin{tabular}{|c|c|c|c|c|}
\hline & Title & Author & Date & for paper \\
\hline WPS2265 & $\begin{array}{l}\text { The Political Economy of Distress } \\
\text { in East Asian Financial Institutions }\end{array}$ & $\begin{array}{l}\text { Paola Bongini } \\
\text { Stijn Claessens } \\
\text { Giovanni Ferri }\end{array}$ & January 2000 & $\begin{array}{l}\text { R. Vo } \\
33722\end{array}$ \\
\hline WPS2266 & $\begin{array}{l}\text { The Impact of Aduit Deaths on } \\
\text { Children's Health in Northwestern } \\
\text { Tanzania }\end{array}$ & $\begin{array}{l}\text { Martha Ainsworth } \\
\text { Innocent Semali }\end{array}$ & January 2000 & $\begin{array}{l}\text { S. Fallon } \\
38009\end{array}$ \\
\hline WPS2267 & $\begin{array}{l}\text { Do High interest Rates Defend } \\
\text { Currencies during Speculative Aitacks }\end{array}$ & $\begin{array}{l}\text { Aart Kraay } \\
\text { ? }\end{array}$ & January 2000 & $\begin{array}{l}\text { R. Bonfield } \\
31248\end{array}$ \\
\hline WPS2268 & $\begin{array}{l}\text { The Structure of Social Disparities } \\
\text { In Education: Gender and Wealth }\end{array}$ & Deon Filmer & January 2000 & $\begin{array}{l}\text { S. Fallon } \\
38009\end{array}$ \\
\hline WPS2269 & $\begin{array}{l}\text { Context is Everything: Measuring } \\
\text { institutional Change in Transition } \\
\text { Economies }\end{array}$ & Nauro F. Campos & January 2000 & $\begin{array}{l}\text { J. Victor } \\
36549\end{array}$ \\
\hline WPS2270 & $\begin{array}{l}\text { The Optimal Income Tax When } \\
\text { Poverty Is a Public "Bad" }\end{array}$ & Waly Wane & January 2000 & $\begin{array}{l}\text { H. Sladovich } \\
37698\end{array}$ \\
\hline MPS2271 & Corporate Risk around the World & $\begin{array}{l}\text { Stijn Claessens } \\
\text { Simeon Djankov } \\
\text { Tatiana Nenova }\end{array}$ & January 2000 & $\begin{array}{l}\text { R. Vo } \\
33722\end{array}$ \\
\hline WPS2272 & $\begin{array}{l}\text { Ownership versus Environment: } \\
\text { Disentangling the Sources of Public } \\
\text { Sector inefficiency }\end{array}$ & $\begin{array}{l}\text { Ann P. Bartel } \\
\text { Ann E. Harrison }\end{array}$ & January 2000 & $\begin{array}{l}\text { S. Fallon } \\
38009\end{array}$ \\
\hline WPS2273 & $\begin{array}{l}\text { The Value of Preventing Malaria } \\
\text { in Tembien, Ethiopia }\end{array}$ & $\begin{array}{l}\text { Maureen L. Cropper } \\
\text { Mitiku Haile } \\
\text { Julian A. Lampietti } \\
\text { Christine Poulos } \\
\text { Dale Whittington }\end{array}$ & January 2000 & $\begin{array}{l}\text { T. Tourougui } \\
87431\end{array}$ \\
\hline
\end{tabular}

